\title{
Enhancement of Yield and Quality Parameters of Withania somnifera by Indigenous Endophytic Bacterial Isolates
}

\author{
Krupali B. Ramanuj* and Harsha N. Shelat \\ Department of Agricultural Microbiology and Biofertilizer Project, B.A. College of \\ Agriculture, Anand Agricultural University, Anand-388110, Gujarat, India \\ *Corresponding author
}

\section{A B S T R A C T}

\begin{tabular}{|l|}
\hline K e y w or d s \\
$\begin{array}{l}\text { Withania somnifera, } \\
\text { Endophytic } \\
\text { bacterial isolates }\end{array}$ \\
\hline Article Info \\
\hline $\begin{array}{l}\text { Accepted: } \\
\text { 24 January } 2018 \\
\text { Available Online: } \\
\text { 10 February } 2018\end{array}$ \\
\hline
\end{tabular}

Ashwagandha (Withania somnifera L. Dunal) is an important medicinal plant containing active constituent withanolides providing anti-stress ability, energy, and immunity. An experiment in Randomized Block Design (factorial) was laid out at medicinal and aromatic plants farm, AAU, Anand to study the effect of individual five endophytic bacterial isolates on growth and yield of $W$. somnifera along with FYM and with/without recommended dose of fertilizer (RDF 30:15:0, N:P:K kg/ha). Amongst two levels of fertilizer doses, F1 receiving RDF was superior to F0 control. Pseudomonas aeruginosa showed significantly higher yield and yield attributing parameters viz. plant height (104.45 $\mathrm{cm})$, no. of branches $(6.50)$, root length $(29.85 \mathrm{~cm})$, root girth $(6.40 \mathrm{~cm})$, green leaves yield $(22698 \mathrm{~kg} / \mathrm{ha})$, dry root yield $(480 \mathrm{~kg} / \mathrm{ha})$ and dry foliage yield $(8574 \mathrm{~kg} / \mathrm{ha})$ when compared with un-inoculated control $(72.30 \mathrm{~cm}, 4.00,19.42 \mathrm{~cm}, 4.35 \mathrm{~cm}, 7907 \mathrm{~kg} / \mathrm{ha}, 280$ $\mathrm{kg} / \mathrm{ha}, 5704 \mathrm{~kg} / \mathrm{ha}$ ), respectively. The results indicated that soil application of endophytic bacteria @ 1L/ha as well as RDF (30:15:0 NPK kg/ha) improved dry root quality parameters starch and withanolides. Endophytic $P$. aeruginosa strain AAU K5 proved to be the best plant growth promoting endophytic bacteria for Ashwagandha.

\section{Introduction}

Withania somnifera (L.) Dunal commonly known as Ashwagandha / Indian ginseng or winter cherry, is one of the most valued medicinal plants used in Indian Ayurveda for $\simeq 3000$ years. The Sanskrit name "ashva" meaning horse and "gandha" meaning smelling was given to this plant due to the smell of the roots resembling a sweating horse. It belongs to the family Solanaceae and attains a height of 0.5-2 $\mathrm{m}$. The whole plant or its different parts are widely used in
Ayurvedic and Unani i.e. indigenous systems of in India for its medicinal properties and has been used since ancient times (Dar et al., 2015).

It is used as herbal medicine in various forms (decoctions, infusions, ointments, powder and syrup) in different parts of the world, for all age groups of patients (Chatterjee et al., 2010). It possesses a wide array of therapeutic properties including anti-arthritic, anti-aging, anti-cancer, anti-inflammatory, immunoregulatory, chemoprotective, cardioprotective 
and recovery from neurodegenerative disorders (Singh et al., 2015). The traditional use of 'Ashwagandha' was to increase energy, youthful vigour, endurance, strength, health, increase vital fluids, muscle fat, blood, lymph, semen and cell production. It helps counteract chronic fatigue, weakness, dehydration, bone weakness, loose teeth, thirst, impotency, premature aging emaciation, debility, convalescence and muscle tension. It helps invigorate the body by rejuvenating the reproductive organs, just as a tree is invigorated by feeding the roots (Ishnava et al., 2012).

The medicinal properties of $W$. somnifera are due to its chemical constituents (alkaloids and withanolides) present primarily in roots and also in leaves. The species is also known as 'Indian ginseng' as its roots possess restorative properties similar to Panax ginseng (Datta et al., 2011). The molecules such as withaferin A, withanolide A and withanolide $\mathrm{D}$ isolated from this plant are potential bioactive molecules. Due to the remarkable biological activity of $W$. somnifera and its constituents, it will be appropriate to develop them as a medicine and make them more potent by chemical modifications and biotransformations (Mir et al., 2014).

Many chemical fertilizers are used to increase the yield of plants and improve the nutritional composition of the plants. But continuous use of chemical fertilizers is reported to have deleterious effects on soil health due to their ill effects on physical, chemical and biological properties of soil. Organic manure contains plant growth regulating materials/ regulators, such as humic acids and auxins like gibberellins and cytokinins which are responsible for improved plant growth and yield of many crops (Kumari et al., 2016). The growing interest in environmental sustainability has led to considerable efforts to minimize the use of chemical fertilizers and pesticides, replacing/integrating these conventional approaches with more ecofriendly methods, such as the application of beneficial microorganisms (Abbamondi et al., 2016).

Endophytes 'hidden' within the host plants are a poorly investigated reserve of microorganisms. Endophytes are relatively unstudied as potential sources of novel natural products for medical and commercial exploitation. Since, there are so many of them occupying literally millions of unique biological niches (higher plants) growing in so many unusual environments, exciting potential exist in the endeavor into the wild and unexplored territories of the world to engage in the discovery of endophytes, their biology and potential usefulness (Mehanni and Safwat, 2010). Endophytic microbes have been under increased investigation due to their intimate interaction with the host; it is believed that the phytochemical constitutes of plants are related either directly or indirectly to endophytes and their interactions with host plants (Egamberdieva et al., 2017).

In this effort, endophytic bacteria were isolated from medicinal plants, established their PGP traits and further confirmed their efficacy on $W$. somnifera.

\section{Materials and Methods}

Total thirty bacterial endophytes were isolated from various plants like Azadirachta indica, Zingibe rofficinale Rosc., Chlorophytum borivilianum, Curcuma longa, Tinospora cordifolia, Withania somnifera and Ocimum sanctum Lin. from various plant parts like leaf, fruit, rhizome and stem using different media viz. Nutrient agar (NA), Starch casein agar (SCA), Glycerol asparagine agar (GAA), Kuster's agar (KUS), King's B (KB) and Inorganic salt starch (ISP4). Further they were screened for in vitro PGP traits viz. phosphate 
solubilization, potash mobilization, production of IAA and siderophore, production of various enzymes like ACC-deaminase, cellulose, protease, lipase, chitinase; antifungal activity and biochemical tests. Five promising endophytic bacterial isolates out of thirty were selected on the basis of PGP traits as stated above. Selected five isolates were then identified on the basis of biochemical and molecular characterization. Isolate Z-1 was identified as Bacillus tequilensis strain AAU $\mathrm{K} 1$ accn. MF034733, $\mathrm{CH}-1$ as Bacillus endophyticus strain AAU K2 acc.no. MF034734, C-1 as Beijerinckia fluminensis strain AAU K3 accn. MF034735, T-1 as Bacillus safensis strain AAU K4 accn. MF034736 and W-1 as Pseudomonas aeruginosa strain AAU K5 accn. MF034737. Nitrogen fixing ability was also confirmed with nif $\mathrm{H}$ gene which was found in three isolates namely isolate $\mathrm{C}-1, \mathrm{~T}-1$ and $\mathrm{W}-1$. Further their efficacy was tested on Ashwagandha (Withania somnifera L. Dunal) along with FYM and with/without recommended dose of fertilizer in pot as well as field.

The research trial was carried out in field at medicinal and aromatic plants research farm of the Anand Agricultural University during October-March 2016. Various physiological and biochemical studies were undertaken both in field as well in laboratory. The soil of the experimental plots was sandy loam, locally known as "Goradu". The soil was well drained and retentive of moisture. It responded well to irrigation and manuring and was reasonably suitable for Ashwagandha cultivation. The field experiment was laid during October 2015 to March 2016 in Randomized Block Design (factorial) with three replications, Gross plot size: 2.7 x $4.0 \mathrm{~m}^{2}$, Net Plot size: $1.8 \times 3.0 \mathrm{~m}^{2}$, seed rate: 7 to $10 \mathrm{~kg} / \mathrm{ha}$, irrigations: 5 to 6 , bacterial treatments: soil drenching at $1 \mathrm{~L} / \mathrm{ha}$ having $10^{9} \mathrm{cfu} / \mathrm{ml}$ as per treatment, crop and variety: Ashwagandha $c v$. GAA-1. Treatments comprised as, B0: control, B1: Bacillus tequilensis, B2: Bacillus endophyticus, B3: Beijerinckia flumensis, B4: Bacillus safensis, B5: Pseudomonas aeruginosa with two levels of fertilizer doses F0: control and F1: RDF (30:15:0 NPK kg/ha). FYM 10 ton/ha was applied common in all plots as basal (Table 1).

Plant observations recorded were; days to flower initiation (no.), plant height $(\mathrm{cm})$, branches/plant (no.), root length $(\mathrm{cm})$, root girth $(\mathrm{cm})$, green leaves yield $(\mathrm{kg} / \mathrm{ha})$, dry root yield ( $\mathrm{kg} / \mathrm{ha})$, dry foliage yield/plant ( $\mathrm{kg} / \mathrm{ha})$, chlorophyll content of leaves $\left(\mu \mathrm{g} / \mathrm{cm}^{2}\right)$ measured by chlorophyll meter (Made: at LEAF Ver. 1.0, WILMINGTON, US) at harvest.

\section{Withanolide content (\%)}

The roots was measured by LC-MS (ekspert ${ }^{\mathrm{TM}}$ ultraLC Systems) technique. For extraction of withanolides, one $\mathrm{g}$ dried root sample powder was taken. To convert it into fine powder with even particles it was crushed in liquid nitrogen. $100 \mathrm{mg}$ of finely powdered root sample was taken in eppendorf vial $(2 \mathrm{ml})$ for further extraction of withanolides. $1.5 \mathrm{ml} \mathrm{50 \%}$ $\mathrm{v} / \mathrm{v}$ Methanol in $1.2 \mathrm{M} \mathrm{HCl}$ was taken and added to the sample. It was sonicated and kept in water bath at $80^{\circ} \mathrm{C}$. Sonication was continued till $1 \mathrm{~h}$ with a break after every 15 min for 1 min (to avoid bumping of solvent).

Centrifugation was carried out at 5,500 rpm for $5 \mathrm{~min}$. Supernatant was transferred to falcon tube $(10 \mathrm{ml})$. To the residue, the solvent was added and extraction was continued as described previously for 5 times. Pooled supernatant was kept at room temperature for evaporation of solvent. Next day, tubes were kept in water bath at $70^{\circ} \mathrm{C}$ till $2 \mathrm{ml}$ was left in tube. It was further filtered using $0.2 \mu \mathrm{m}$ syringe filter (Axiva). This was directly used as sample. 
Estimation of the withanolide content of roots of Ashwagandha was carried out using liquid chromatography (LC) connected to a mass spectrometer (MS). For liquid chromatography, a QTRAP 4500 ion trap mass spectrometer (ABSCIEX) was connected to the Ekspert ultra LC 100 (Eksigent) instrument via an ESI interface. For liquid chromatography ultra LC 100 from Eksigent was used in conjunction with ABSCIEX QTRAP 4500 mass analyser. The LC-100 was equipped with degasser, quaternary pump, column oven and auto-sampler. Gradient elution was optimized for getting good resolution and noise control during acquisition. For Liquid Chromato-graphy ACQUITY UPLC-BEH C18 (2.1 X $50 \mathrm{~mm}$, $1.7 \mu \mathrm{m})$ column (WATER Company make) was used.

The column temperature and sample temperature were maintained at $65^{\circ} \mathrm{C}$ and $4^{\circ} \mathrm{C}$ respectively. The mobile phase was (A: 10\%) water and (B: 90\%) Methanol $(\mathrm{MeOH})$ with $0.1 \%$ formic acid each. The gradient column elution was as follows: (i) $0 \mathrm{~min}, 95 \% \mathrm{~A}$ and $5 \% \mathrm{~B}$; (ii) 0-2 min, $90 \% \mathrm{~A}$ and $10 \% \mathrm{~B}$; (iii) $2-$ $15 \mathrm{~min}, 50 \% \mathrm{~A}$ and $50 \% \mathrm{~B}$; (iv) 15-22 min, $50 \% \mathrm{~A}$ and $50 \% \mathrm{~B}$; (v) 22-24 min, $10 \% \mathrm{~A}$ and $90 \% \mathrm{~B}$; (vi) 24-25 min, $10 \% \mathrm{~A}$ and $90 \% \mathrm{~B}$; (vii) $25-35 \mathrm{~min}, 10 \% \mathrm{~A}$ and $90 \% \mathrm{~B}$ and (viii) $35-60 \mathrm{~min}, 95 \% \mathrm{~A}$ and $5 \% \mathrm{~B}$. The flow rate of the mobile phase was set to $0.4 \mu 1 / \mathrm{ml}$ with an injection volume fixed at $5 \mu 1$.

\section{Starch content}

Starch content was estimated by Anthrone method described by MacCready (1950). Dry root powder $200 \mathrm{mg}, 5 \mathrm{ml}$ of distilled water and $25 \mathrm{ml}$ of $80 \%$ ethyl alcohol were taken in $50 \mathrm{ml}$ centrifuge tube and centrifuged at 8000 rpm for 6 min., supernatant was discarded, to the pellet $30 \mathrm{ml}$ of $80 \%$ ethyl alcohol was added and centrifuged again, supernatant was discarded, to the residue $20 \mathrm{ml}$ of distilled water plus $6.5 \mathrm{ml}$ of perchloric acid was added and centrifuged. Repeated twice and then transferred the aqueous phase to $100 \mathrm{ml}$ volumetric flask and final volume made up to $100 \mathrm{ml}$. One $\mathrm{ml}$ of filtrate was taken and diluted to $100 \mathrm{ml}$ with distilled water. Again 5 $\mathrm{ml}$ from this was taken and $10 \mathrm{ml}$ of freshly prepared $10 \%$ anthrone reagent was added and boiled for $7.5 \mathrm{~min}$ in boiling water bath.

The tubes were allowed to cool down at room temperature and read at $630 \mathrm{~nm}$ in spectrophotometer. Starch content was calculated as per the following formula:

Starch \% = O.D. $\times$ Graph factor $\times 0.9$

\section{Soil microbial population (cfu/g)}

Soil samples were collected before sowing and at the time of harvest from different treatments separately and stored in polythene bags and kept in refrigerator till processed. Bacterial counts were done by taking $10 \mathrm{~g}$ soil sample in sterile $90 \mathrm{ml} \mathrm{D} / \mathrm{W}$ and shaken it for $1 \mathrm{~h}$ and $0.5 \mathrm{ml}$ sample was taken aseptically from it and transferred in $4.5 \mathrm{ml} \mathrm{D} / \mathrm{W}$ containing dilution tube to make up to $10^{-6}$ dilutions by serial dilution method from which $0.1 \mathrm{ml}$ aliquot was spreaded on NA plates, incubated for 24-48 $\mathrm{h}$ and colony counts were taken for calculating cfu/g.

$$
\text { Soil bacterial population cfu/g }=\frac{\text { No. of colonies } x \text { dilution factor }}{\text { Aliquottaken }}
$$

\section{Results and Discussion}

A field trail was laid out during October 2015 to March 2016 at Medicinal and Aromatic farm AAU, Anand. Data regarding efficacy of endophytic bacterial PGPB isolates on flower initiation, plant height, branches per plant, root length, root girth, green leaves weight per 
plant, dry root weight, dry biomass weight and leaf chlorophyll content of Withania somnifera (L.) Dunal are described below.

\section{Days to flower initiation (No.)}

The results indicated that the fertilizer dose and bacterial treatment showed significant influence on days to flower initiation. The data (Table 2) indicated that days to flowering was significantly the least in the fertilizer dose F1 (59.61) as compared to F0 (62.22). Treatment B5 receiving soil application of $P$. aeruginosa showed early days to flowering (53.67) as compared to other bacterial treatments. Effect of FxB interaction was non-significant.

\section{Plant height (cm)}

In an experiment to study effect of bacterial treatment and fertilizers in ashwagandha under field conditions, data (Table 3) indicated that plant height was found significant. Dose F1 gave significantly the highest plant height $(92.17 \mathrm{~cm})$ as compared to F0 $(87.42 \mathrm{~cm})$. Among various bacterial treatments, B5 showed significantly the highest plant height $(104.45 \mathrm{~cm})$ when compared with all the other treatments and it was found at par with treatment B2 $(102.30 \mathrm{~cm})$. Effect of FxB interaction was non-significant.

\section{Branches/plant (no.)}

The results presented in Table 4 indicated that the fertilizer dose and bacterial treatment showed their significant influence on number of branches per plant. The mean data indicated that number of branches per plant was significantly the highest in F1 (5.78) as compared to F0 (5.17).

Among different bacterial treatments, B5 gave the highest number of branches (6.50) which was at par with B2. Effect of FxB interaction was non-significant.

\section{Root length (cm)}

Soil application of all the 5 bacterial treatments and fertilizer doses had significant effect on growth and development of Ashwagandha roots which is represented in Table 5. Root length was found significantly the highest in F1 $(25.31 \mathrm{~cm})$ as compared with F0 $(24.08 \mathrm{~cm})$. Bacterial treatment B5 gave significantly the highest root length (29.85 $\mathrm{cm}$ ) when compared with all the other treatments.

The effect of FxB interaction was found significant. Treatment F1B5 was found at par with treatment F0B5 suggesting that for organic farming of ashwagandha, treatment F0B5 receiving soil application of $P$. aeruginosa with fertilizer comprising basal FYM can be applied and for conventional farming treatment F1B5 comprising soil application of $P$. aeruginosa with fertilizer dose RDF can be beneficial. Also treatment F1B2 was found at par with treatment F0B2.

\section{Root girth (cm)}

Soil application of all the 5 bacterial treatment had significant effect on growth and development of Ashwagandha roots which is represented in Table 6. Effect of fertilizer dose was found non-significant. Bacterial treatment B5 gave significantly the highest root girth $(6.40 \mathrm{~cm})$. Effect of FxB interaction was found non-significant.

\section{Green leaves yield (kg/ha)}

Data (Table 7) indicated that green leaves yield was found significant. Dose F1 gave significantly the highest green leaves yield $(15776 \mathrm{~kg} / \mathrm{ha})$ as compared to F0 (15370 $\mathrm{kg} / \mathrm{ha}$ ). Among various bacterial treatments, B5 showed significantly the highest yield (22698 kg/ha). Effect of FxB interaction was found non-significant. 
Table.1 Treatment details

\begin{tabular}{|c|c|c|c|}
\hline Factor B & Bacterial isolate & Factor $\mathbf{F}$ & Fertilizer \\
\hline B0 & Control & F0 & Control \\
\hline B1 & Bacillus tequilensis strain AAU K1 & F1 & RDF : N:P:K (30:15:0) kg/ha \\
\hline B2 & Bacillus endophyticusstrain AAU K2 & & \\
\hline B3 & Beijerinckia fluminensis strain AAU K3 & & \\
\hline B4 & Bacillus safensis strain AAU K4 & & \\
\hline B5 & Pseudomonas aeruginosa strain AAU K5 & & \\
\hline
\end{tabular}

Table.2 Days to flower initiation (No.)

\begin{tabular}{|c|c|c|c|c|c|c|c|}
\hline \multirow{2}{*}{$\begin{array}{l}\text { Fertilizer } \\
\text { dose (F) }\end{array}$} & \multicolumn{6}{|c|}{ Bacterial treatment (B) } & \multirow[b]{2}{*}{ Mean F } \\
\hline & B0 & B1 & B2 & B3 & B4 & B5 & \\
\hline F0 & 71.33 & 66.33 & 56.33 & 60.67 & 63.67 & 55.00 & 62.22 \\
\hline F1 & 68.67 & 61.67 & 56.00 & 57.67 & 61.33 & 52.33 & 59.61 \\
\hline Mean B & 70.00 & 64.00 & 56.17 & 59.17 & 62.50 & 53.67 & \\
\hline Effect & B & $\mathbf{F}$ & $\mathbf{B x F}$ & & & & \\
\hline S.Em. \pm & 0.80 & 0.46 & 1.13 & & & & \\
\hline lsd & 2.35 & 1.36 & NS & & & & \\
\hline CV\% & & 3.22 & & & & & \\
\hline
\end{tabular}

Table.3 Plant height (cm)

\begin{tabular}{|c|c|c|c|c|c|c|c|}
\hline \multirow{2}{*}{$\begin{array}{l}\text { Fertilizer dose } \\
\text { (F) }\end{array}$} & \multicolumn{6}{|c|}{ Bacterial treatment (B) } & \multirow[b]{2}{*}{ Mean F } \\
\hline & B0 & B1 & B2 & B3 & B4 & B5 & \\
\hline F0 & 66.13 & 84.60 & 101.57 & 91.37 & 78.54 & 102.33 & 87.42 \\
\hline F1 & 78.47 & 90.40 & 103.03 & 94.20 & 80.37 & 106.57 & 92.17 \\
\hline Mean B & 72.30 & 87.50 & 102.30 & 92.78 & 79.45 & 104.45 & \\
\hline Effect & B & $\mathbf{F}$ & BxF & & & & \\
\hline S.Em. \pm & 1.67 & 0.97 & 2.37 & & & & \\
\hline lsd & 4.91 & 2.84 & NS & & & & \\
\hline CV\% & & 4.57 & & & & & \\
\hline
\end{tabular}

Table.4 Branches/plant (no.)

\begin{tabular}{|c|c|c|c|c|c|c|c|}
\hline Fertilizer dose (F) & \multicolumn{7}{|c|}{ Bacterial treatment (B) } \\
\hline & B0 & B1 & B2 & B3 & B4 & B5 & Mean F \\
\hline F0 & 3.33 & 5.33 & 6.00 & 4.67 & 5.33 & 6.33 & 5.17 \\
\hline F1 & 4.67 & 5.67 & 6.00 & 6.00 & 5.67 & 6.67 & 5.78 \\
\hline Mean B & 4.00 & 5.50 & 6.00 & 5.33 & 5.50 & 6.50 & \\
\hline Effect & B & F & BxF & & & & \\
\hline S.Em. \pm & 0.29 & 0.17 & 0.41 & & & & \\
\hline Isd & 0.85 & 0.49 & NS & & & \\
\hline CV\% & & 12.89 & & & & \\
\hline
\end{tabular}


Table.5 Root length $(\mathrm{cm})$

\begin{tabular}{|c|c|c|c|c|c|c|c|}
\hline $\begin{array}{c}\text { Fertilizer } \\
\text { dose }(\mathbf{F})\end{array}$ & B0 & B1 & B2 & B3 & B4 & B5 & Mean F \\
\hline F0 & 17.30 & 22.73 & 27.13 & 23.87 & 22.53 & 29.03 & 24.08 \\
\hline F1 & 21.53 & 24.03 & 27.23 & 25.73 & 24.50 & 30.67 & 25.31 \\
\hline Mean B & 19.42 & 23.38 & 27.18 & 24.80 & 23.52 & 29.85 & \\
\hline Effect & B & F & BxF & & & & \\
\hline S.Em. \pm & 0.52 & 0.30 & 0.74 & & & & \\
\hline Isd & 1.53 & 0.89 & 2.16 & & & & \\
\hline CV\% & & 5.16 & & & & \\
\end{tabular}

Table.6 Root girth $(\mathrm{cm})$

\begin{tabular}{|c|}
\hline $\begin{array}{c}\text { Fertilizer dose } \\
(\text { F) }\end{array}$ \\
\hline F0 \\
\hline F1 \\
\hline Mean B \\
\hline Effect \\
\hline S.Em. \pm \\
\hline Isd \\
\hline CV\% \\
\hline
\end{tabular}

Bacterial treatment (B)

\begin{tabular}{|c|c|c|c|c|c|c|}
\hline \multicolumn{7}{|c|}{ Bacterial treatment (B) } \\
\hline B0 & B1 & B2 & B3 & B4 & B5 & Mean F \\
\hline 3.90 & 4.83 & 5.87 & 5.57 & 5.50 & 6.23 & 5.32 \\
\hline 4.80 & 4.93 & 5.93 & 6.00 & 5.77 & 6.57 & 5.67 \\
\hline 4.35 & 4.88 & 5.90 & 5.78 & 5.63 & 6.40 & \\
\hline B & F & BxF & & & & \\
\hline 0.22 & 0.13 & 0.31 & & & & \\
\hline 0.64 & NS & NS & & & & \\
\hline & 9.78 & & & & & \\
\hline
\end{tabular}

Table.7 Green leaves yield (kg/ha)

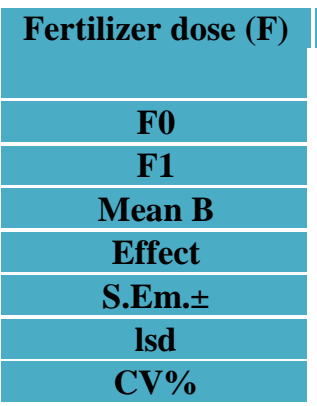

\begin{tabular}{|c|c|c|c|c|c|c|}
\hline \multicolumn{7}{|c|}{ Bacterial treatment (B) } \\
\hline B0 & B1 & B2 & B3 & B4 & B5 & Mean F \\
\hline 7,337 & 14,233 & 18,692 & 15,944 & 13,378 & 22,633 & 15,370 \\
\hline 8,478 & 14,570 & 18,978 & 16,126 & 13,741 & 22,763 & 15,776 \\
\hline 7,907 & 14,402 & 18,835 & 16,035 & 13,559 & 22,698 & \\
\hline B & F & BxF & & & & \\
\hline 216 & 125 & 305 & & & & \\
\hline 637 & 368 & NS & & & & \\
\hline & 2.74 & & & & & \\
\hline
\end{tabular}

Table.8 Dry root yield (kg/ha)

\begin{tabular}{|c|}
$\begin{array}{c}\text { Fertilizer dose } \\
(\text { F })\end{array}$ \\
\hline F0 \\
\hline F1 \\
\hline Mean B \\
\hline Effect \\
\hline S.Em. \pm \\
\hline Isd \\
\hline CV\% \\
\hline
\end{tabular}

\begin{tabular}{|c|c|c|c|c|c|c|}
\hline \multicolumn{7}{|c|}{ Bacterial treatment (B) } \\
\hline B0 & B1 & B2 & B3 & B4 & B5 & Mean F \\
\hline 244 & 327 & 373 & 368 & 353 & 436 & 350 \\
\hline 316 & 353 & 420 & 410 & 412 & 534 & 407 \\
\hline 280 & 340 & 397 & 389 & 382 & 485 & \\
\hline B & F & BxF & & & & \\
\hline 20 & 12 & 29 & & & & \\
\hline 60 & 35 & NS & & & & \\
\hline & 13.15 & & & & & \\
\hline
\end{tabular}


Table.9 Dry foliage yield (kg/ha)

\begin{tabular}{|c|c|c|c|c|c|c|c|}
\hline $\begin{array}{c}\text { Fertilizer } \\
\text { dose (F) }\end{array}$ & B0 & B1 & B2 & B3 & B4 & B5 & Mean F \\
\hline F0 & 5,595 & 5,958 & 7,565 & 8,281 & 6,839 & 8,187 & 7,071 \\
\hline F1 & 5,813 & 6,373 & 7,913 & 8,773 & 7,085 & 8,960 & 7,486 \\
\hline Mean B & 5,704 & 6,165 & 7,739 & 8,527 & 6,962 & 8,574 & \\
\hline Effect & B & F & BxF & & & & \\
\hline S.Em. & 216 & 125 & 305 & & & & \\
\hline Isd & 637 & 368 & NS & & & \\
\hline CV\% & & 7.26 & & & & \\
\hline
\end{tabular}

Table.10 Chlorophyll content of leaves $\left(\mu \mathrm{g} / \mathrm{cm}^{2}\right)$

\begin{tabular}{|c|c|c|c|c|c|c|c|}
\hline $\begin{array}{c}\text { Fertilizer } \\
\text { dose }(\mathbf{F})\end{array}$ & B0 & B1 & B2 & B3 & B4 & B5 & Mean F \\
\hline Fo & 64.16 & 63.74 & 65.23 & 65.61 & 62.79 & 64.69 & 64.37 \\
\hline F1 & 64.77 & 64.16 & 66.43 & 66.57 & 64.34 & 65.35 & 65.27 \\
\hline Mean B & 64.47 & 63.95 & 66.09 & 65.83 & 63.56 & 65.01 & \\
\hline Effect & B & F & BxF & & & & \\
\hline S.Em. & 0.805 & 0.465 & 1.139 & & & & \\
\hline Isd & NS & NS & NS & & & & \\
\hline CV\% & & 3.04 & & & & & \\
\hline
\end{tabular}

Table.11 Active constituent's estimation

\begin{tabular}{|c|c|c|c|c|}
\hline & & \multicolumn{3}{|c|}{ Active constituents mg/g of dry root } \\
\hline $\begin{array}{c}\text { Sr. } \\
\text { No. }\end{array}$ & Treatment & Withanolide & Withaferin-A & $\begin{array}{c}\text { 12- } \\
\text { Deoxywithastramonolide }\end{array}$ \\
\hline $\mathbf{1}$ & F0B0 & 0.130 & 0.020 & 0.209 \\
\hline $\mathbf{2}$ & F0B1 & 0.151 & 0.032 & 0.237 \\
\hline $\mathbf{3}$ & F0B2 & 0.190 & 0.038 & 0.302 \\
\hline $\mathbf{4}$ & F0B3 & 0.203 & 0.022 & 0.336 \\
\hline $\mathbf{5}$ & F0B4 & 0.174 & 0.035 & 0.270 \\
\hline $\mathbf{6}$ & F0B5 & 0.248 & 0.030 & 0.396 \\
\hline & & & & \\
\hline $\mathbf{7}$ & F1B0 & 0.146 & 0.023 & 0.229 \\
\hline $\mathbf{8}$ & F1B1 & 0.159 & 0.035 & 0.253 \\
\hline $\mathbf{9}$ & F1B2 & 0.203 & 0.053 & 0.320 \\
\hline $\mathbf{1 0}$ & F1B3 & 0.226 & 0.024 & 0.338 \\
\hline $\mathbf{1 1}$ & F1B4 & 0.187 & 0.038 & 0.294 \\
\hline $\mathbf{1 2}$ & F1B5 & 0.282 & 0.068 & 0.434 \\
\hline
\end{tabular}


Table.12 Starch content (\%)

\begin{tabular}{|c|c|c|c|c|c|c|c|}
\hline $\begin{array}{c}\text { Fertilizer } \\
\text { dose (F) }\end{array}$ & B0 & B1 & B2 & B3 & B4 & B5 & Mean F \\
\hline F0 & 10.23 & 13.20 & 14.40 & 16.10 & 13.83 & 18.37 & 14.36 \\
\hline F1 & 10.57 & 13.60 & 15.13 & 16.27 & 14.10 & 18.83 & 14.75 \\
\hline Mean B & 10.40 & 13.40 & 14.77 & 16.19 & 13.97 & 18.60 & \\
\hline Effect & B & F & BxF & & & & \\
\hline S.Em. \pm & 0.10 & 0.06 & 0.15 & & & & \\
\hline Isd & 0.30 & 0.17 & 0.43 & & & & \\
\hline CV\% & & 1.73 & & & & & \\
\hline
\end{tabular}

Table.13 Soil bacterial population ( $\log \mathrm{cfu} / \mathrm{g})$

\begin{tabular}{|c|c|c|c|c|c|c|c|}
\hline $\begin{array}{c}\text { Fertilizer dose } \\
\text { (F) }\end{array}$ & \multicolumn{7}{|c|}{ Bacterial treatment (B) } \\
\hline & B0 & B1 & B2 & B3 & B4 & B5 & Mean F \\
\hline F0 & 5.50 & 6.41 & 6.62 & 6.54 & 6.51 & 6.79 & 6.39 \\
\hline F1 & 5.56 & 6.44 & 6.63 & 6.57 & 6.52 & 6.82 & 6.42 \\
\hline Mean B & 5.53 & 6.43 & 6.63 & 6.65 & 6.52 & 6.81 & \\
\hline Effect & B & F & BxF & & & & \\
\hline S.Em. & 0.005 & 0.008 & NS & & & \\
\hline Isd & 0.024 & 0.014 & NS & & & \\
\hline CV\% & 0.311 & & & & & \\
\end{tabular}

Fig.1 Effect of endophytic bacterial isolates on dry root of Ashwagandha

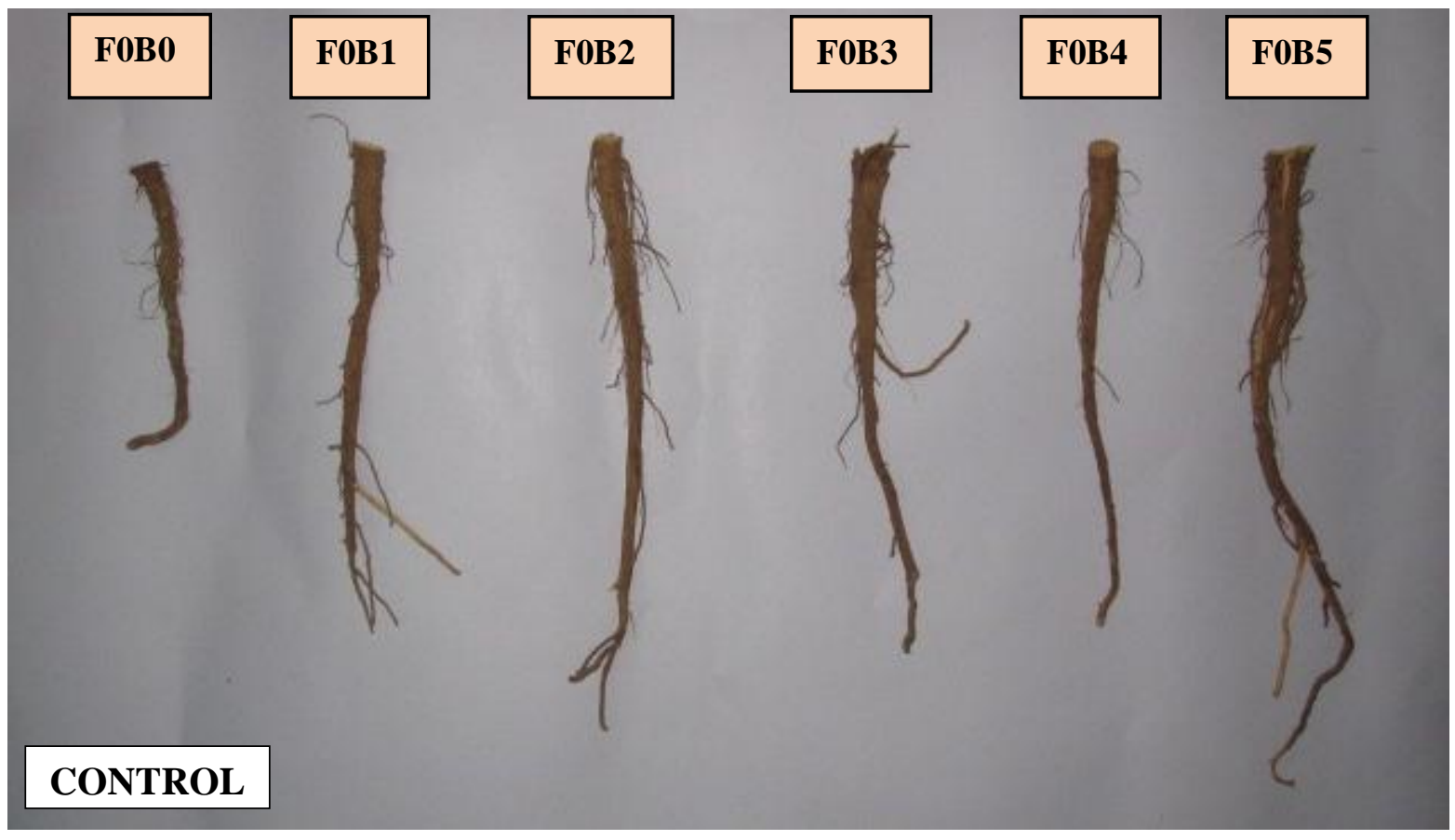




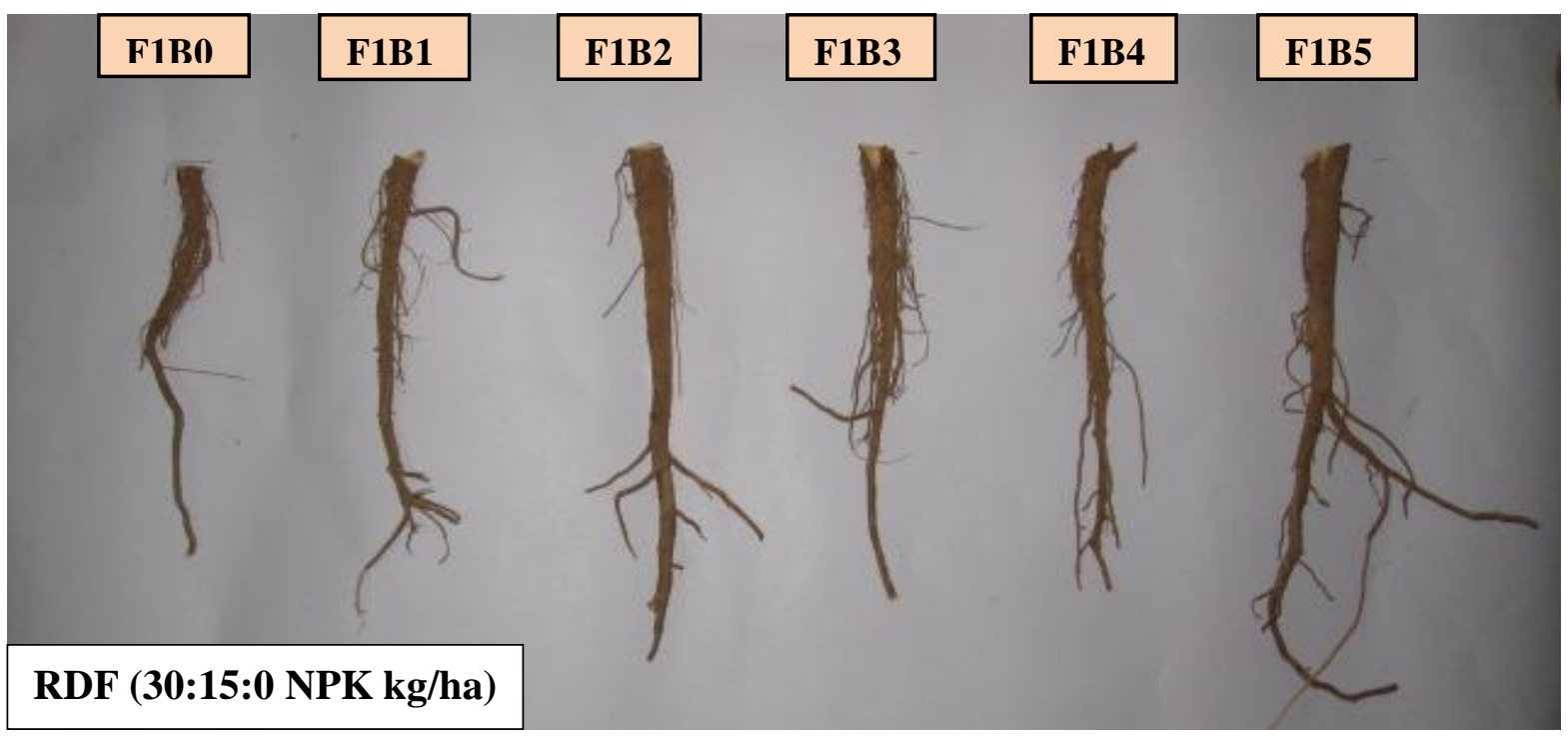

\section{Dry root yield $(\mathrm{kg} / \mathrm{ha})$}

Data (Table 8) indicated that dry root yield was found significant. Dose F1 gave significantly the highest dry root yield (407 $\mathrm{kg} / \mathrm{ha})$ as compared to F0 (350 kg/ha). Among various bacterial treatments, B5 showed significantly the highest yield $(485 \mathrm{~kg} / \mathrm{ha})$ when compared with all the other treatments. Effect of FxB interaction was found nonsignificant (Fig. 1). Shrivastava and Sahu (2014) studied the yield and quality parameters of $W$. somnifera using integrated nutrient management with the use of organic manures in combination with inorganic fertilizers and micro-nutrient improved the quality parameters of root of ashwagandha crop. Among all the treatments, T11 treatment receiving 100\% NPK and $2.5 \mathrm{t} / \mathrm{ha}$ vermicompost as well as $5 \mathrm{t} / \mathrm{ha} \mathrm{FYM}$ with $20 \mathrm{~kg}$ $\mathrm{ZnSO}_{4}$ excelled to all the treatments followed by T14, T10 and T13 in terms of root length, girth and dry root yield. It was minimum under $\mathrm{T} 2$ where $50 \%$ RDF was applied through fertilizers.

Kumar et al., (2009) studied the yield parameters and cost economics of $W$. somnifera using dual inoculation of
Azotobacter chroococcum and Pseudomonas putida. Inoculation with the bacteria generated encouraging results wherein, fresh root yield (1185.6 $\left.\mathrm{kg} \mathrm{ha}^{-1}\right)$, seed yield (208.13 $\mathrm{kg} \mathrm{ha}^{-1}$ ), number of shoots per plant (6.07), and plant height $(108.4 \mathrm{~cm})$ were maximum with treatment T6 (organic manure [OM] $20 \mathrm{t}$ $\mathrm{ha}^{-1}+$ both bacteria), followed by T9 (OM 10 $\mathrm{t} \mathrm{ha}^{-1}+$ both bacteria), T4 (OM $20 \mathrm{t} \mathrm{ha}^{-1}+A$. chroococcum), and T5 (OM $20 \mathrm{t} \mathrm{ha}^{-1}+P$. putida), as compared to T1 (control), T2 (OM $\left.10 \mathrm{tha}^{-1}\right)$, and T3 (OM $\left.20 \mathrm{t} \mathrm{ha}^{-1}\right)$.

\section{Dry foliage yield (kg/ha)}

Data (Table 9) indicated that dry foliage yield was found significant. Dose F1 gave significantly the highest dry foliage yield (7486 kg/ha) as compared to F0 (7071 kg/ha). Among various bacterial treatments, B5 showed the highest dry foliage yield (8574 $\mathrm{kg} / \mathrm{ha}$ ) which was at par with B3 (8527 $\mathrm{kg} / \mathrm{ha}$ ). Effect of interaction was found nonsignificant.

\section{Chlorophyll content of leaves $\left(\mu \mathrm{g} / \mathrm{cm}^{2}\right)$}

Data (Table 10) indicated that chlorophyll content of leaves was found non-significant. 


\section{Withanolide}

Three important bioactive compounds namely withaferin-A (WA), 12-deoxy withastramonolide (WO) and withanolide-A (WD) were determined by the liquid chromatography mass spectrometry (LC-MS) method in dry roots of $W$. somnifera. Withanolide content ranged from 0.130 to $0.282 \mathrm{mg} / \mathrm{g}$ of dry root.

Treatment B5 gave the highest withanolide content as compared to un-inoculated control. Withaferin content ranged from 0.020 to $0.068 \mathrm{mg} / \mathrm{g}$ of dry root. Treatment B5 gave the highest withaferin content as compared to un-inoculated control. 12-Deoxy withastramonolide content ranged from 0.209 to $0.434 \mathrm{mg} / \mathrm{g}$ of dry root. Treatment B5 gave the highest 12-Deoxy withastramonolide content as compared to un-inoculated control (Table 11).

Gajbhiye et al., (2015) studied accumulation of three important bioactive compounds in different plant parts of $W$. somnifera and its determination by LC-ESI-MS-MS (MRM) method. The accumulation of WA was the highest in leaves $(8.84 \pm 0.37 \mathrm{mg} / \mathrm{g})$ and it was $2.23,5.85$ and 27.26 times higher than its concentration in fruits, stems and roots, respectively. WO and WD contents were the highest $(0.44 \pm 0.016$ and $0.72 \pm 0.016 \mathrm{mg} / \mathrm{g}$, respectively) in root.

\section{Starch estimation}

Starch estimation was carried out from the dry root samples. Data (Table 12) indicated that starch content was found significant. Dose F1 gave significantly the highest starch content $(14.75 \%)$ as compared to F0 (14.36 \%). Among various bacterial treatments, B5 showed the highest starch content $(18.60 \%)$. Effect of interaction was found significant.
Treatment F1B5 was found at par with treatment F0B5. Also treatment F1B3 was found at par wih treatment F0B3.

Kakaraparthi et al., (2013) studied Effect of sowing dates on morphological characteristics, root yield and chemical composition of the root of $W$. somnifera grown in the semi-arid regions of Andhra Pradesh, India. Among the varieties tested, Poshita produced significantly high starch content $(19.55 \%)$ compared to variety Nagore $(15.33 \%)$. Early sowing (June-July) resulted in higher root yield. The starch content showed decrease-increase-decrease pattern with delay in sowings. By and large on an average there is a steady decrease in starch content with advancement in sowings from June to October.

Kumar et al., (2011) studied the root textural quality in ashwagandha as influenced by crop growth periods and morphotypes. They observed that the pattern of starch and fiber accumulation varied with different crop growth periods. The pattern of root starch accumulation at different growth intervals followed a trend of decrease-increasedecrease. Starch content was high at early stage of the crop growth 45 DAS (17.44\%), decreased gradually up to middle of crop growth 105 DAS $(11.10 \%)$, thereafter replenished (120 DAS - 14.45\%; 135 DAS $15.37 \%)$ and then depleted 150 DAS $(14.18 \%)$ and at 165 DAS (13.12\%).

Khanna et al., (2006) studied the biochemical composition of $W$. somnifera (L.) Dunal. Starch contents were measured in five selective accessions viz. AGB-002, AGB-009, AGB-015, AGB-025 and AGB-030 of $W$. somnifera (L.) Dunal. Measured activity of starch in roots was found to be involved in root development and composition showing increased trend in activities measured in selected five accessions at maturity stage i.e., 
210 Days after planting (DAP) ranging from $7.98 \pm 0.20$ to $9.46 \pm 0.08 \mathrm{mg} \mathrm{g}^{-1}$. Young roots at 150 DAP showed low amount of starch ranging from $6.09 \pm 0.13$ to $8.87 \pm 0.25 \mathrm{mg} \mathrm{g}^{-1}$.

\section{Soil bacterial population}

Initial soil population of bacteria was $3.53 \mathrm{log}$ $\mathrm{cfu} / \mathrm{g}$. Data (Table 13) indicated that soil bacterial count was found significant. Dose F1 gave significantly the highest bacterial count $(6.42 \log \mathrm{cfu} / \mathrm{g})$ as compared to F0 (6.39 $\log \mathrm{cfu} / \mathrm{g})$. Among various bacterial treatments B5 showed significantly the highest bacterial count $(6.81 \log \mathrm{cfu} / \mathrm{g})$ when compared with all the other treatments. Interaction was found to be non-significant.

The efficacy of bacterial endophytes was tested on Ashwagandha (Withania somnifera L. Dunal) along with FYM and with/without recommended dose of fertilizer in field. The results indicated soil application of B5 $P$. aeruginosa showed significantly higher growth parameters viz. plant height, no. of branches, root length, root girth, green leaves yield, dry root yield and dry foliage yield when compared with uninoculated control. Similarly, amongst two levels of fertilizer doses, F1 was superior to F0. The results indicated that soil application of endophytic bacteria@1L/ha as well as RDF (30:15:0 NPK $\mathrm{kg} / \mathrm{ha}$ ) increased yield and yield attributing parameters with improved quality namely starch and withanolides of Ashwagandha dry root. Endophytic Pseudomonas aeruginosa strain AAU K5 Accn MF034737 proved to be the best plant growth promoting endophytic bacteria for Ashwagandha.

\section{Acknowledgements}

I would like to express my sincere thanks to Department of Agricultural Microbiology and Biofertilizer Project as well as Medicinal and
Aromatic plants research station, Anand Agricultural University, Anand for infrastructural support. I would extend my thanks to Dr. M. A. Patel, Professor, Medicinal and Aromatic plants research station and Mr. Amar Sakure, Assistant Research Scientist, Department of Agricultural Biotechnology, Anand for guidelines.

\section{References}

Abbamondi G.R., Sillen W., Panagiotisgkorezis, Carmine I., Wesley M., Rangel, Barbara N. and Vangronsveld J. (2016). Plant growthpromoting effects of rhizospheric and endophytic bacteria associated with different tomato cultivars and new tomato hybrids. Chem. Biol. Technol. Agric. 3:1.

Chatterjee S.,Srivastava S., Khalid A., Singh N., Singh R., Sangwan, Sidhu O.P., Raja Roy, Khetrapal C.L., Tuli R. (2010) Comprehensive metabolic fingerprinting of Withania somnifera leaf and root extracts. Phytochem, Pp. 1085-1094.

Dar J., Hamid A. and Ahmad M. (2015). Pharmacologic overview of Withania somnifera, the Indian Ginseng. Cell. Mol. Life Sci. (2015) 72: 4445-4460.

Datta A., Das A., Bhattacharya A., Mukherjee S. and Ghosh B. (2011). An overview of Withania sominerfa (L.) Dunal the 'Indian ginseng'. Med Aromat Plant Sci Biotechnol, 5(1), 1-15.

Egamberdieva D., Wirth S., Undine Behrendt U., Ahmad P. and Berg G., (2017) Antimicrobial Activity of Medicinal Plants Correlates with the Proportion of Antagonistic Endophytes. Front Microbiol, Volume 8:199.

Gajbhiye N., Makasana J. and Kumar S. (2015). Accumulation of Three Important Bioactive Compounds in 
Different Plant Parts of Withania somnifera and its Determination by the LC-ESI-MS-MS (MRM) Method. $J$ Chromatogr Sc, Pp. 1-8.

Ishnava, Kalpesh B., Patel T. and Chauhan J.B. (2012). Study of Genetic Transformation of Medicinal Plants, Withania somnifera (L.) Dunal By Agrobacterium tumefaciens (MTCC431) Asian J. Exp. Bio., 3(3) 2012: 536542.

Kakaraparthi P.S., Rajput D.K., Komaraiah K., Kumar N. and Kumar R.R. (2013). Effect of Sowing Dates on Morphological Characteristics, Root Yield and Chemical Composition of the Root of Withania somnifera Grown in the Semi-Arid Regions of Andhra Pradesh, India. J Sci Res Rep, 2(1): 121132.

Khanna P., Kumar A., Ahuja A. and Kaul M. (2006). Biochemical composition of roots of Withania somnifera (L.) Dunal. Asian J Plant Sci, 5(6): 1061-1063.

Kumar R.R., Reddy L.P.A., Niranjana Kumar A., Komaraiah S., Purnan K. and Sastry K.P. (2011). Root textural quality in ashwagandha (Withania somnifera) as influenced by crop growth periods and Morphotypes. Ind Crops Prod, 34:1231-1234.

Kumar V., Solanki A.S. and Sharma S. (2009). Yield and economics of Withania somnifera influenced by dual inoculation of Azotobacter chroococcum and Pseudomonas putida. Turk J Biol, 33:219-223.

Kumari M., Shweta and Upadhyay R.G. (2016). Influence of the organic manures, plantation time and spacing on physiological and biochemical parameters of ashwagandha. Journal of Hill Agriculture 7(1): 32 - 35.

McCready R.M., Guggolz J., Silviera V. and Owens H.S. (1950). Determination of Starch and Amylose in Vegetables. Anal. Chem., 22(9), pp 1156-1158.

Mehanni M.M. and Safwat M.S. (2010). Endophytes of medicinal plants, Isolation and characterization of plant growth promoting endophytic bacteria from the rhizome of Zingiber officinale. Acta Hort (ISHS), 4:197-204.

Mir B., Mir S. and Koul S. (2014). In vitro propagation and withaferin A production in Withania ashwagandha, a rare medicinal plant of India. Physiol Mol Biol Plants, 20(3):357-364

Shrivastava A. K. and Sahu K. S. (2014) Yield and Quality Parameters of Alkaloids of Withania somnifera (L.) Dunal. Intl J Agron Plant Prod, 4(12): 3246-3254.

Singh P., Guleri R., Singh V., Kaur G., Kataria H., Singh B., Kaur G., Kaul S., Wadhwa R. and Pati P. (2015). Biotechnological interventions in Withania somnifera (L.) Dunal. Biotechnol Genet Eng Rev, 31:1-2.

\section{How to cite this article:}

Krupali B. Ramanuj and Harsha N. Shelat. 2018. Enhancement of Yield and Quality Parameters of Withania somnifera by Indigenous Endophytic Bacterial Isolates. Int.J.Curr.Microbiol.App.Sci. 7(02): 2569-2581. doi: https://doi.org/10.20546/ijcmas.2018.702.313 